This item was submitted to Loughborough's Research Repository by the author.

Items in Figshare are protected by copyright, with all rights reserved, unless otherwise indicated.

\title{
Introduction to the special thematic symposium on the ethics of controversial online advertising
}

PLEASE CITE THE PUBLISHED VERSION

http://dx.doi.org/10.1007/s10551-015-2754-6

\section{PUBLISHER}

(C) Springer

VERSION

AM (Accepted Manuscript)

\section{PUBLISHER STATEMENT}

This work is made available according to the conditions of the Creative Commons Attribution-NonCommercialNoDerivatives 4.0 International (CC BY-NC-ND 4.0) licence. Full details of this licence are available at: https://creativecommons.org/licenses/by-nc-nd/4.0/

\section{LICENCE}

CC BY-NC-ND 4.0

\section{REPOSITORY RECORD}

Moraes, Caroline, and Nina Michaelidou. 2019. "Introduction to the Special Thematic Symposium on the Ethics of Controversial Online Advertising”. figshare. https://hdl.handle.net/2134/17794. 


\title{
Introduction to the Special Thematic Symposium on the Ethics of Controversial \\ Online Advertising
}

\author{
Guest Editorial \\ Journal of Business Ethics
}

Dr Caroline Moraes and Dr Nina Michaelidou

\begin{abstract}
The field of marketing and consumer ethics has evolved considerably over the past twenty years, yet research on specific areas of advertising ethics remains limited. This limitation persists despite developments in digital technologies, and the impact they have had on advertising practice generally and online advertising more specifically. Online media are becoming increasingly populated by advertising content as consumers continuously navigate ever-evolving mediascapes. Thus, there is a need to examine the ethical issues associated with the use of controversial advertising online, as well as consumers' responses to such ads. Consequently, this special symposium addresses this literature gap, which is at the intersection of consumer ethics, emarketing and controversial advertising. The two papers in this special symposium present new research in this area, along with some initial practical recommendations as well as potential for future research.
\end{abstract}

\section{Key words}

Advertising ethics; online advertising; controversial advertising; consumer ethics. 


\section{Introduction}

Over the past twenty years impactful research has been carried out in the field of consumer and marketing ethics (Hunt and Vitell, 2006; Nwachukwu et al., 1997; Vitell, 2001; Vitell, 2003; Vitell et al., 2001; Vitell et al., 2009), yet research on specific areas of advertising ethics remains limited. Ethical issues in advertising have been explored particularly in relation to matters of deception (Polonsky et al., 1998; Spurgin, 2003), representation (Sandikci, 2001; Schroeder and Borgerson, 2005), targeting of vulnerable populations (Nairn and Berthon, 2003; Bakir and Vitell, 2010), the morality of advertising and advertising professionals (Maes et al., 1998; Shaver, 2003; Beltramini, 2006), advertising of contentious products (Wilson and West, 1981; Wong, 1996; Fam and Waller, 2003), advertising as persuasive ideology (Hackley and Kitchen, 1999; Cunningham, 2003), and also in works which seek to provide a vision for the characteristics of responsible ads (Hyman, 2009).

Similarly, controversial advertising has received limited research attention. Controversial advertising can be defined as advertising which aims to shock or offend audiences through the violation of norms, and such ads are perceived by audiences to be provocative or obscene (Dahl et al., 2003). Controversial advertising may involve the advertising of products perceived as controversial in their own right, the usage of advertising appeals such as sex and fear (Benet et al., 1993; Camenisch, 1991; Henthorne and LaTour, 1995; Waller, 2006), and execution styles which are perceived as controversial or ethically contentious (Waller, 2006; Nebenzahl and Jaffe, 1998). Indeed, few journals have devoted specific attention to the ethical issues involved in controversial advertising, with the exception of a 2008 special issue of the Journal of Marketing Communications (cf. Erdogan, 2008; Dens et al., 2008). 
This scarcity of research on controversial advertising persists despite developments in digital technologies, and the impact they have had on mediascapes (Appadurai, 1990) and the increased use of online platforms for controversial advertising purposes. Evidence of the increased incidence of controversial online advertising is reflected on social media companies' policies regarding such ads. In its AdSense programme, for example, Google (2015) presents sixteen advertising categories (e.g., sexuality, cosmetic procedures and body modification, astrology and religion) and two restricted categories (i.e. alcohol, and gambling and betting), which are considered sensitive. Consumers can then 'block' such ad categories in order to reduce the potential for exposure to such controversial advertising messages (Google, 2015).

Furthermore, while some researchers have addressed the ethics of electronic commerce practices (Charters, 2002; Palmer, 2005; Stead and Gilbert, 2001), and other business ethics issues brought about by recent technological developments (Linton and Walsh, 2012), hardly any research has focused on controversial advertising on social media, despite the fact that ad spend on those platforms has risen considerably in recent years (eMarketer, 2014), and that consumers want better ethics in online advertising (Snyder, 2011).

All of these research gaps provided the impetus for this special thematic symposium in the Journal of Business Ethics, which aimed to draw additional research attention to the use of controversial advertising in online platforms. Thus, this symposium is at the intersection of consumer ethics, e-marketing and controversial advertising, and 
provides new insights into the ethical issues associated with the use of controversial advertising online, as well as on consumers' responses to such online ads.

\section{Contents of the symposium}

The special thematic symposium consists of two papers, which address diverse aspects of controversial online advertising and consumer responses to such ads.

The first article by Ouidade Sabri investigates issues related to the use of controversial taboo appeals (i.e. sexuality and death) in online viral communication, and the impact of different media contexts (i.e. press versus social media) on the effectiveness of such controversial taboo ads. The author uses an experimental design involving a 2x2 between-subject experiment with a sample of French respondents, which is then replicated for external validity purposes. The results highlight that the communication medium influences consumers' perceptions of the tabooness level of a controversial ad, as well as perceived subjective norms. In particular, the author's study shows that consumers downplay the tabooness of a viral controversial ad placed on a social networking site compared to that of an ad embedded in a press article. The study also suggests that controversial viral advertising does not contribute to building favourable brand attitudes and purchase intentions. Concurrently, the author highlights the importance of subjective norms in an online context, where perceptions of the tabooness of an ad are shaped by friends who share the online ad content. The study yields a number of ethical implications and highlights the need for additional regulations and policies on online viral advertising. 
The second study by Selma Kadic-Maglajlic and colleagues examines social media advertising executed with controversial sexual appeals, and focuses on a number of antecedents and outcomes. Specifically, the study examines the role of ethical judgment and religious commitment in shaping consumers' controversial ad perceptions on a social networking site, which in turn impacts attitude towards the ad, attitude towards the brand, and purchase intentions. The authors use a quantitative research design and conduct their study in Bosnia and Herzegovina, and employ structural equations modelling to analyse the data. Research results shed light on the moderating role of religious commitment, suggesting that even though a controversial ad on Facebook is perceived as ethically acceptable, consumers with a high level of religious commitment will still perceived it as controversial. Additionally, the authors find that controversial ad perceptions shape attitude towards the ad as well as purchase intentions, and outline a number of implications for both academic researchers and advertisers who seek to improve advertising effectiveness without shocking consumers.

Both papers contribute to an area of enquiry that has remained considerably underresearched. They highlight key theoretical and practical implications, and the need for further consideration of the ethics of controversial advertising. The special thematic symposium represents an initial attempt to address this topical research area and we hope it will stimulate further research on controversial advertising online and its ethical implications. 


\section{Acknowledgements}

We would like to express our gratitude to the reviewers who helped with the reviewing process and provided constructive comments to the authors of this special symposium. Furthermore, we extend our appreciation to the editorial office for their continuous support. Finally, we would like to thank the section editor, Professor Thomas Maak, for providing us the opportunity to organise this special thematic symposium.

\section{References}

Appadurai, A. (1990). Disjuncture and Difference in the Global Cultural Economy. Theory, Culture \& Society, 7(2), 295-310. DOI:10.1177/026327690007002017

Bakir, A. and Vitell, S. (2010). The Ethics of Food Advertising Targeted Toward Children: Parental Viewpoint. Journal of Business Ethics, 91(2), 299-311. DOI: 10.1007/s10551-009-0084-2

Beltramini, R. F. (2006). Consumer Believability of Information in Direct-toConsumer (DTC) Advertising of Prescription Drugs. Journal of Business Ethics, 63(4), 333-343. DOI: 10.1007/s10551-005-4711-2

Benet, S., Pitts, R. E. and LaTour, M. (1993). The Appropriateness of Fear Appeal use for Health Care Marketing to the Elderly: Is it OK to Scare Granny? Journal of Business Ethics, 12(1), 45-55. DOI: 10.1007/BF01845786

Camenisch, P. F. (1991). Marketing Ethics: Some Dimensions of the Challenge. Journal of Business Ethics, 10(4), 245-248. DOI: 10.1007/BF00382961

Charters, D. (2002). Electronic Monitoring and Privacy Issues in Business-Marketing: The Ethics of the DoubleClick Experience. Journal of Business Ethics, 35(4), 243-254. DOI: 10.1023/A:1013824909970 
Cunningham, A. (2003). Autonomous Consumption: Buying into the Ideology of Capitalism. Journal of Business Ethics, 48(3), 229-236. DOI: 10.1023/B:BUSI.0000005784.48184.d6

Dahl, D. W., Frankenberger, K. D. and Manchanda, R. V. (2003). Does It Pay to Shock? Reactions to Shocking and Nonshocking Advertising Content among University Students. Journal of Advertising Research, 43(03), 268-280. DOI: 10.1017/S0021849903030332.

Dens, N., P., De Pelsmacker, P. and Janssens, W. (2008). Exploring Consumer Reactions to Incongruent Mild Disgust Appeals. Journal of Marketing Communications, 14(4), 249-269. DOI: 10.1080/13527260802141231

eMarketer. (2014). Online Ad Spending in Europe Topped €27 Billion in 2013. May 29. http://www.emarketer.com/Article/Online-Ad-Spending-Europe-Toppedeuro27-Billion-2013/1010870

Erdogan, B. Z. (2008). Controversial Advertising. Journal of Marketing Communications, 14(4), 247-248. DOI: 10.1080/13527260802141462

Fam, K. S. and Waller, D. S. (2003). Advertising Controversial Products in the Asia Pacific: What Makes them Offensive? Journal of Business Ethics, 48(3), 237250. DOI: 10.1023/B:BUSI.0000005785.29778.83

Google. (2015). Sensitive Ad Categories. https://support.google.com/adsense/answer/3016445?hl=en

Hackley, C. E. and Kitchen, P. J. (1999). Ethical Perspectives on the Postmodern Communications Leviathan. Journal of Business Ethics, 20(1), 15-26. DOI: 10.1023/A:1005933424439 
Henthorne, T. L. and LaTour, M.S. (1995). A Model to Explore the Ethics of Erotic Stimuli in Print Advertising. Journal of Business Ethics, 14(7), 561-569. DOI: 10.1007/BF00871984

Hunt, S. D. and Vitell, S. J. (2006). The General Theory of Marketing Ethics: A Revision and Three Questions. Journal of Macromarketing, 26(2), 143-153. DOI: $10.1177 / 0276146706290923$

Hyman, M. (2009). Responsible Ads: A Workable Ideal. Journal of Business Ethics, 87(2), 199-210. DOI: 10.1007/s10551-008-9879-9

Linton, J. D. and Walsh, S. T. (2012). Introduction to the Field of Nanotechnology Ethics and Policy. Journal of Business Ethics, 109 (4), 547-549. DOI: 10.1007/s10551-012-1428-X

Maes, J. D., Jeffery, A. and Smith, T. V. (1998). The American Association of Advertising Agencies (4As) Standards of Practice: How Far does this Professional Association's Code of Ethics' Influence Reach? Journal of Business Ethics, 17(11), 1155-1161. DOI: 10.1023/A:1005790324722

Nairn, A. and Berthon, P. (2003). Creating the Customer: The Influence of Advertising on Consumer Market Segments - Evidence and Ethics. Journal of Business Ethics, 42(1), 83-99. DOI: 10.1023/A:1021620825950

Nebenzahl, I. D. and Jaffe, E. D. (1998). Ethical Dimensions of Advertising Executions. Journal of Business Ethics, 17(7), 805-815. DOI: 10.1023/A:1005850812845

Nwachukwu, S. L. S., Vitell, S. J., Gilbert, F. W. and Barnes, J. H. (1997). Ethics and Social Responsibility in Marketing: An Examination of the Ethical Evaluation of Advertising Strategies. Journal of Business Research, 39(2), 107-118. DOI: http://www.sciencedirect.com/science/article/pii/S0148296396001464 
Palmer, D. E. (2005). Pop-Ups, Cookies, and Spam: Toward a Deeper Analysis of the Ethical Significance of Internet Marketing Practices. Journal of Business Ethics, 58(1-3), 271-280. DOI: 10.1007/s10551-005-1421-8

Polonsky, M. J., Bailey, J., Baker, H., Basche, C., Jepson, C. and Neath, L. (1998). Communicating Environmental Information: Are Marketing Claims on Packaging Misleading? Journal of Business Ethics, 17(3), 281-294. DOI: 10.1023/A:1005731914135

Sandikci, O. (2001). Living with Contradictions: Representational Politics and Politics of Representation in Advertising. Advances in Consumer Research, 28(1), 309-314. DOI: http://acrwebsite.org/volumes/8496/volumes/v28/NA-28

Schroeder, J. E. and Borgerson, J. L. (2005). An Ethics of Representation for International Marketing Communication. International Marketing Review, 22 (5), 578-600. DOI: http://dx.doi.org/10.1108/02651330510624408

Shaver, D. (2003). Toward an Analytical Structure for Evaluating the Ethical Content of Decisions by Advertising Professionals. Journal of Business Ethics, 48(3), 291-300. DOI: 10.1023/B:BUSI.0000005787.46742.93

Snyder, W. (2011). Making the Case for Enhanced Advertising Ethics. Journal of Advertising $\quad$ Research, $\quad$ 51(3), 477-483. http://www.jar.warc.com/ArticleCenter/default.asp?ID=95186\&Type=Article

Spurgin, E. W. (2003). What's Wrong with Computer-Generated Images of Perfection in Advertising? Journal of Business Ethics, 45(3), 257-268. DOI: 10.1023/A:1024155629554

Stead, B. A. and Gilbert, J. (2001). Ethical Issues in Electronic Commerce. Journal of Business Ethics, 34(2), 75-85. DOI: 10.1023/A:1012266020988 
Vitell, S., Bing, M., Davison, H., Ammeter, A., Garner, B. and Novicevic, M. (2009). Religiosity and Moral Identity: The Mediating Role of Self-Control. Journal of Business Ethics, 88(4), 601-613. DOI: 10.1007/s10551-008-9980-0

Vitell, S. J., Singhapakdi, A. and Thomas, J. (2001). Consumer Ethics: An Application and Empirical Testing of the Hunt-Vitell Theory of Ethics. Journal of Consumer Marketing, 18(2), 153-178. DOI: http://dx.doi.org/10.1108/07363760110386018

Vitell, S. J. (2001). Introduction to Special Issue on Marketing Ethics. Journal of Business Ethics, 32(1), 1-2. DOI: 10.1023/A:1010686807048

Vitell, S. J. (2003). Consumer Ethics Research: Review, Synthesis and Suggestions for the Future. Journal of Business Ethics, 43(1), 33-47. DOI: 10.1023/A:1022907014295

Waller, D. (2006). A Proposed Response Model for Controversial Advertising. Journal of Promotion Management, 11(2/3), 3-16. DOI: 10.1300/J057v11n02_02

Wilson, A. and West, C. (1981). The Marketing of 'Unmentionables'. Harvard Business Review, 59 (1), 91-102. Available from: http://web.a.ebscohost.com/ehost/pdfviewer/pdfviewer?sid=15e6b122-a36c4045-9b8a-ed6f90eea146\%40sessionmgr4001\&vid=24\&hid=4114

Wong, K. L. (1996). Tobacco Advertising and Children: The Limits of First Amendment Protection. Journal of Business Ethics, 15(10), 1051-1064. DOI: 10.1007/BF00412046 